\title{
Love, Faith, Religion and Colonialization: Cultural Insight in the Soul of Archipelago Literature
}

\author{
Hadijah bte Rahmat \\ Nanyang Technological University, Singapore \\ hadijah.rahmat@,nie.edu.sg
}

\begin{abstract}
This paper discusses the role of literature in the development of culture, country, world and humanity of the people. The great literary work is not only beautiful artfully in terms of language and its shape, it can even give insights into thinking, science, values and soul, which can instill and develop the culture and civilization of a nation or country. In short, literature can function as an agent of cultural reconstruction and transformation. Traditional literature of the archipelago has revealed the vision and philosophy of exquisite Malay culture and serves as an institution or discourse of public education. These are all clearly revealed in pantun, proverbs, precept or poems of their peoples. The role of literature in the reconstruction and transformation of the culture was continued by new or modern literature as reflected by the works of Munsyi Abdullah (1796-1854), RA Kartini (1879-1904), Sutan Takdir Alisjahbana (1908-1994), HAMKA (1908- 1981), Amir Hamzah (1911-1946) and Chairil Anwar (1922-1949). Cultural insights that discussing love, cultural customs, religion and occupation occurred in the works of HAMKA and the impact of the writing will be discussed.
\end{abstract}

Keywords-- culture, Malay, local wisdom, HAMKA

\section{INTRODUCTION}

Interest in the matter of culture in Indonesia has emerged, grew and developed more or less a century ago. It began with the Congress on the Development of Javanese Culture in Surakarta, Solo, in 1918. The focus of the congress talks is more on Javanese culture and areas such as Sunda, Madura and Bali. Post-independence cultural congress was held by the name of Indonesian Cultural Congress in Magelang on August 20-25, 1948, with the theme "Culture and Community Development." It was considered as the first national cultural congress of Indonesia. This cultural activity and discourse continues to this day. Indonesian Ministry of Education and Culture (Kemendikbud) through the Directorate General of Culture carry out workshops on the preparation of regional cultural as the Implementation of Law Number 5 of 2017 concerning the Advancement of Culture. At present, this is being intensified in preparation for the 100-year Indonesian cultural congress, which will take held in November 2018.

Among the cultural ideas that are important to be discussed in congressional activities so far are: A nation's culture cannot be stopped or static and Indonesian culture must accept elements of other cultures actively and critically (Jakarta Congress, 1950); Hatta gave the view of human cultural ties with the nature of God se creation (Congress in Bandung, 1952); Culture is "collecting three elements of human life activities, namely science, philosophy and art" (Solo Congress, 1954); The view of Ki Hajar Dewantara, or Raden Mas Soewardi Soeryaningrat as "Father of Indonesian Education", Indonesian culture is the culmination of regional culture that is accepted by all Indonesian people into Indonesian culture.

\section{METHOD}

Indonesian thinkers have examined and given meaning or meaning to the term or etymology of the word 'Culture.' According to HAMKA (1960), in the article of national culture seminars in Bandung entitled "Culture Looked at in terms of Islamic Teachings":

“ Kata kebudayaan itu tersusun dari dua kata - yang tadinya terpisah - yaitu budi dan daya. Kata budi berarti cahaya atau bersinar yang terletak di dalam batin manusia. Kata ini sudah sangat tua usianya sehingga dipakai juga menjadi nama dari satu ajaran agama yang dibawa olah Gaotama Budha. Daya bertalian dengan upaya, yaitu usaha, keaktifan manusia melaksanakan dengan anggotanya yang digerakkan oleh budinya" (HAMKA, 2016, p. 239-240).

This is repeated by the great Indonesian writer and thinker, Sutan Takdir Alishjahbana (1985) in his writings, "The Duties of Art in Our Times":

" konsep kebudayaan dalam bahasa Indonesia, langsung diturunkan dari konsep budi, yang masih ada hubungan dengan perkataan „Buddha ${ }^{e e}$ (yang mendapat cahaya). Dari perkataan „,budi ${ }^{\text {ee }}$ ini timbul perkataan 
„budi-daya" atau „Budayae, iaitu daya, usaha atau hasil daripada budi” (S.T.Alisjahbana, Seni dan Sastera, Di Tengah-tengah Pergolakan Masyarakat dan Kebudayaan, 2008, p. 1).

Sutan Takdir Alisjahbana explained that a unique cultural value that distinguishes humans from animals: "menurut tanggapan ini adalah budi manusia yang unik yang memungkinkan manusia menciptakan kebudayaan dan hidup dalam kebudayaan. Jadi berbeda sekali dari hewan yang merupakan makhluk alam yang hidup dalam alam atas dasar ,drives" atau dorongan hidup dan instinctnya" (ibid).

Other than the uniqueness of human culture, one of the cultural characteristics identified by Alisjahbana is its dynamic value:

"Budi manusia sebagai suatu system yang terbuka dan dinamis, dan yang oleh kesanggupan menilai, dia selalu berada dalam proses penilaian, yaitu, menciptakan nilai-nilai yang menjadi inti kelakuan dan perhubungan kebudayaan manusia".

In his book, Values as Integrating Forces in Personality, Society and Cultures: Essay of a New Anthropology, ST Alisjahbana (1985) also emphasizes the characteristics of values in the human culture system. Humans as unique creatures, who are cultured, have a tendency to judge and are always in the evaluation process, in other words is the ability to create values that are at the core of behavior and the relationships of fellow members of society or human culture.

“..budi manusia sebagai system yang terbuka dan dinamis, dan oleh kesanggupan menilai dia selalu berada dalam proses penilaian, yaitu menciptakan nilai-nilai yang menjadi inti kelakuan dan perhubungan kebudayaan manusia."

Sutan Takdir has also followed Edward Spranger's view of giving six values in culture:

1. Theoretical value (incarnated in science and knowledge)

2. Economic value (utility)

3. Religious value (holiness)

4. Aesthetic value (expresiveness)

5. Vertical social value (political power)

6. Horizontal social value (solidarity-incarnate as love, friendship and cooperation)

Malay civilization has inherited us with a concept of ,budi' (mind) and ,civilized man'. According to Malay cultural philosophy, a superior human being desired by the community is a person who is civilized or who is considered a cultured human being. According to Zainal Kling (1995) Malays see the appearance and appearance of mind, which is a personality that contains reason and taste. Budi (mind) is a soul and daya (power) is physical motion. Malay personality has a face of ,budi' (mind) containing a matter of logic and feeling. Budi is regarded as a Malay"s deep structure or inner structure which comes out of one of the highest wisdom (God).

"Budi mempunyai rumpunnya atau gugusan yang bersiratan iaitu akal-budi, budi-bicara, budi-bahasa, budi-pekerti. Gugusan budi atau rumpun budi (budi complex) dapat dibahagikan kepada dua yang bersiratan antara satu sama lain, ibarat kulit dengan isi, luar-dalam, lahir-batin, jasmani-rohani, Kulit, luar, lahir, jasmani merupakan struktur luaran (surface structure) atau permukaan, fizikal, material, fiil, meliputi persoalan budi-pekerti dan budi-bahasa. Isi, dalam, batin, rohani merupakan struktur dalaman (deep structure) meliputi akal-budi, hati-budi dan budi bicara...."

It is manifested in socio-cultural and spiritual clusters which include: kindness to God (God); kindness to nation and motherland kindness to the nature; kindness to society and culture; kindness to family; kindness to own self.

Penerapan nilai budiman bertujuan untuk melahirkan manusia Melayu yang halus, berhati mulia, berakal, bijaksana, beradat, beradab, tahu membalas budi, cukup ajar dan sebagainya. Budi dan budiman ialah teras humanisme, morality dan etika Melayu, yang berpaksikan ketuhanan (ketauhidan) yang mampu meletakkan manusia ke darjat, harkat dan martabat tertinggi...Manusia Melayu yang memiliki nilai dan berorientasikan budi disebut sebagai manusia budiman yang melambangkan a total personality, a perfect gentleman. Dari konsep manusia budiman inilah lahir masyarakat budiman. Konsep budi dan budiman inilah teras kemanusiaan Melayu yang bukan self-centred, man-centred, tetapi juga berpaksikan ketuhanan (God-centred)." (Norazit Selat dan Zainal Abidin Borhan 1996, p. 29-31).

Specific discussions on culture in terms of Islamic teachings are conducted by HAMKA. HAMKA explains that, since Islam teaches the relationship of faith (belief in God) and good deeds, a Muslim is also a humanist:

"Iman yang menerangi hatinya membentuk akal budinya. Akal budinya mendorongnya untuk beramal saleh....Oleh karena itu kebudayaan yang ditimbulkan oleh akal budi yang berpelitakan Islam itu niscaya 
kebudayaan yang bebas dari pengaruh segala sesuatu, kecuali dari Allah. Memandang bahawasanya alam ini seluruhnya adalah ,bahan mentah"e yang disediakan Allah untuk diolah oleh manusia” (HAMKA, 2016, p. 243).

HAMKA has explained the contribution of Islam that has been actively filling to Indonesian culture. For example, in terms of apparel, Islam has provided beautiful dress; giving Jawi, Malay and Pegon letters to literature; enhancing the Malay language through the writing of Hamzah Fansuri, Raja Ali Haji, Abdullah bin Abdul Kadir Munsyi; enlivening and inspiring mosque every Friday, contributing of Wali Songo to Javanese philosophy, Mangkunegara giving Javanese songs in the soul of the Islamic tasawuf, and strengthening the spirit of mutual cooperation which is centered on surau or mosque (HAMKA, 2016, pp. 246-247).

\section{THE ROLE OF WRITER IN SOCIETY AND CULTURE}

\section{FINDING AND DISCUSSION}

\section{The Writer as the voice of the People and the Age}

Writers or litterateurs and societies are often talked and it is acknowledged that both are mutually influencing and difficult to separate. Generally, writers are highly regarded in society as they are considered a spokesperson and the creator of its society and times. Albert Camus, considers artists or writers as "witnesses and voices for those who cannot speak" (in Plekhanov, 1978).

George Lukacs, a literary critic, states that one of the writer's tasks is to give a complete picture of human personality and street's settlers and guides for those who are still in darkness. Therefore, they always take the most actual and important problems in the community as the starting point of their work; and their sorrow as writers is often driven by the most urgent suffering of the people at that time. It is this suffering that determines the object and direction of their love and hate and this feeling that determines their poetic vision or point of view (Lukacs, 1972, p. 12).

A good writer, according to him again, as evidenced by their masterpieces, not only acting as the voice of the community, should also be active as he wrote: "Writers should be champions of social progress and a participant in the social life of his time and not a mere spectator and observers" (Ibid., p.144)

Besides being the spokesperson for the community, the author must be the spokesperson of their age:

" they penetrate deeply into the great universal problems of their time and inexorably depict the true essence of reality as they see it... Writer should depict the spirit and morals of the age and present a whole social milieu instead of moving in a rarified atmosphere of great political event” (Ibid, p.13, p. 70).

\section{The Writer as a Fighter in Extensive Cultural Reconstruction}

The role, duties and responsibilities of the author also received the attention of archipelago thinkers. S. T. Alishjahbana has affirmed the duties and social functions of artists from a broad cultural reconstruction:

"Untuk dapat memenuhi fungsi sosial dan kebudayaan untuk masa depan, jelaslah si seniman mesti sasar sepenuh-penuhnya akan zamannya dan mengerti akan soal-soal masyarakat serta kebudayaan yang kompleks dan bersimpang siur dewasa ini. Hanya dengan demikian ia akan dapat memberi sokongan kepada tugas yang maha besar untuk rekonstruksi dan reintegrasi sosial dan kebudayaan dalam zamannya dengan membuka perspektif yang luas dan kemungkinan-kemungkinan serba ragam masa depan dan menanamkan suatu kreativitas yang gembirakan generasi yang sedang tumbuh" (Alisjahbana, 2008, p. $11)$.

He also reminded the artists not to be trapped and drifted in mass culture, but on the other hand, should function responsibly as a broader cultural fighter:

"Saya sungguh-sungguh berharap bahawa aliran kehilangan tanggungjawab dan tujuan ini tidak berkuasa di Indonesia, sebab artinya tak lain akan berkuasalah mass culture: sastera akan sejajar dengan pertandingan bola dan pertandingan tinju di mana massa yang menentukan nilainya. Seni mass culture ini bersifat komersialisma, yaitu seni perdagangan yang sejalan dengan dehumanisasi. Lenyapnya martabat manusia dengan nilai-nilainya yang khas. Dalam zaman yang penuh pertentangan, penuh ancaman dan bahaya seperti sekarang kita tak dapat menyerahkan pemikiran dan perjuangan cita-cita untuk manusia dan dunia baru kepada resepsi masyarakat, kepada anggapan mass culture. Dalam zaman yang seperti ini si seniman dan teristimewa penulis yang memakai bahasa sebagai alat keseniannya, tak mungkin hanyut menyerahkan dirinya kepada arus resepsi massa, tetapi dengan bebas dan penuh tanggungjawab harus memperjuangkan cita-cita, martabat dan pengertian kebudayaan yang luas." (Alisjahbana, "Sastera Yang Bertanggungjawab pada Permulaan Bangkitnya Kebudayaan Umat Manusia Yang Baru”, 2008, p. 126)

To fulfill that responsibility, artists and litterateurs are expected to have a broad perspective and positive creativity with a glowing vision of life and as a witness to a bright future: 
"Si seniman kreatif yang baru, yang sadar akan tugasnya dalam masyarakat dan kebudayaan yang akan datang sebagai orang di puncak gunung yang menyaksikan dan mengelu-elukan fajar menyingsing untuk hari baru, sedangkan orang lain masih tidur lelap dalam lembah yang gelap" (Alisjahbana, "Tugas Seni di Zaman Kita", 2008, p. 13).

\section{THE ROLE OF TRADITIONAL MALAY LITERATURE IN CULTURE POETRY as the Mirror of Malay's Wisdom}

Traditional Indonesian literature has fulfilled its cultural role very well. This is clearly filled through various forms or genres of his work, oral or written, and in the form of poetry and prose. Compared to the prose genre, traditional poetry has become the most striking means of pronunciation from the philosophy of mind and also the most comprehensive and representative taste of the common people. For example pantun, proverb, expression, nazam, seloka and gurindam, quite a lot in expressing the values, thoughts and voices of the people so referred to as people"s literature. While classical or traditional prose such as historical literature and epic is more to reflect the values and thoughts of powerful groups, such as the king or noble man.

The values and functions of traditional poetry, especially Malay expressions are considered as:

“,salah satu piawaian dan kearifan orang Melayu di dalam menyampaikan fikiran, gagasan, perasaan dan tunjuk ajar Melayu...yang disusun dengan menggunakan kata-kata yang indah, singkat, padat, mengandungi falsafah dan sarat makna, yang berintikan nilai-nilai luhur budaya Melayu yang dianuti masyarakatnya." (Tenas Effendy, 2012,p. 1)

\section{NEW LITERATURE AND THE RECONSTRUCTION OF ARCHIPELAGO CULTURE Literature as Torchlight for the People}

Throughout the colonial period, we witnessed the rise of the authors "e voices, those who try to raise awareness in society against the unfortunate fate of nations and states. This is started from Munsyi Abdullah, Tuan Simi, Raden Adjeng Kartini, Amir Hamzah, Sunan Takdir Alishbana, Harun Aminurashid, Chairil Anwar, Pramoedya Ananta Toer, Muhd Ariff Ahmad, Masuri SN and many more. The above writers have acted as a brightening torch fot their community.

In general, Archipelago literatures consider literature as an important device in the development of people"s morals and souls. The movement of modern Malay / Indonesian literature has so far demonstrated the awareness of the writers and artists to promote and uphold the dignity of the nation or its civilization through the medium of language and literature. They showed their openness and willingness to continue learning new languages, and information and communication technology, as well as new sciences introduced through new languages and technologies. The source of knowledge is not limited to the Islamic world, but also from western civilization.

Besides Munsyi Abdullah, Raden Adjeng Kartini is a Javanese figure who has utilized the knowledge of the Western society to develop her nation and country. Identify the following citation of Kartinies pen:

"Ibu Ovink-Soer, bukanlah laki-laki yang hendak kami lawani, melainkan pendapat kolot dan adat usang, yang tiada gunanya bagi tanah Jawa kami"

"Kami gadis-gadis masih terantai kepada adat istiadat lama.."

"perempuan itu hendaklah juga mendapat pelajaran, bukan sahaja supaya bebas, melainkan supaya dapat merasakan bebas dalam segala hal, supaya terbuka matanya."

"Ibu Abendanon, Bukankah itu memperkosa kodrat alam namanya, bila perempuan dipaksa berdamai tinggal serumah dengan madunya?"

"Bila aku nanti jadi guru... aku hendak mengubah adat yang sudah using turun-temurun itu”.... ***

"Ibu Ovink-Soer,

"Jalan kepada Allah dan jalan kepada padang kemerdekaan hanyalah satu. Siapa yang sesungguhnya jadi hamba Allah, sekali-kali tiada terikat kepada seseorang manusia, sebenar-benarnya merdekalah dia."

("Surat pada Nyonya Ovink-Soer", Oktober 1900)

Abdullah and Kartini are thinkers and the modernist archipelago has used various sources of knowledge (West \& East) for themselves and their work. Their pioneering thoughts were continued by other Archipelago "s thinkers.

In the 1930s for example, Angkatan Pujangga Baru (New Poet Forces) under the leadership of Sutan Takdir Alisjahbana, has given birth to a new spirit to develop Indonesian society. The concept of art held by Angkatan Pujangga Baru is "Art as the driving force of the new spirit, nation"s servants on the way to greatness and glory."

Angkatan Pujangga Baru earned their inspiration from "The Tachtigers" (Generation of 1880s) in the Netherlands that had brought radical innovation in Dutch literature. The characteristic of joining-minded was impressed by this Angkatan Pujangga Baru, which attempts to apply the value of Western art in Indonesian literature. Sutan Takdir 
Alisjahbana and other writers such as Armijn Pane, want to bring renewal in the literature and way of life of Indonesian society and they have recognized the West as a stream of progress, to be dived, leave the lake of peace or perceived Indonesian traditions have hampered their progress:

Kami telah meninggalkan engkau

Tasik yang tenang, tiada beriak

Diteduhi gunung yang rimbun

Dari angin dan topan

Sebab sekali kami terbangun

Dari mimpi yang nikmat.....

Ketenangan lama rasa beku

Gunung pelindung rasa pengalang

Berontak hati hendak bebas

Menyerang segala apa mengadang

(Alisjahbana, "Menuju Ke Laut Angkatan Baru”)

\section{The Voice of Universal Humanism}

After the Second World War, a new generation of writers which is called as Angkatan 45 or Independence Force or Chairil Anwar's forces was born. They were not only pursues the dreams of progress pioneered by the Force of Alisjahbana and Amir Hamzah, what is more interesting is that these young writers no longer want to be regarded as citizens in narrow group, but want to be accepted as a citizen of world literature because the world has now become a source of inspiration and their references:

"Kami adalah ahli waris yang sah dari kebudayaan dunia dan kebudayaan ini kami teruskan dengan cara kami sendiri. Kami lahir dari kalangan orang banyak dan pengertian rakyat bagi kami adalah kumpulan campur-baur dari mana dunia-dunia baru yang sihat dapat dilahirkan...Kalau kami berbicara tentang kebudayaan Indonesia, kami tidak kepada melap-lap hasil kebudayaan lama sampai berkilat dan untuk dibanggakan, tetapi kami memikirkan suatu penghidupan kebudayaan baru yang sihat. Kebudayaan Indonesia ditetapkan oleh kesatuan berbagai rangsang suara yang disebabkan suara-suara yang dilontarkan dari sudut dunia dan kemudian dilontarkan kembali dalam bentuk suara sendiri. Kami akan menentang segala usaha-usaha yang akan mempersempitkan dan menghalangi tidak betulnya pemeriksaan ukuran nilai." ("Surat kepercayaan Gelanggang”, dalam majalah SIASAT, 22.10.1950)

That was a loud voice of the group of young writer after the Great War which is so thirsty for renewal and progress.

Their source of renewal and perspective are much wider - to the world or the universe. Their awareness and hope to be the children of the universe or their universal humanist conception may be clearly illustrated through the following statements: "The world is our pain, because we are the legitimate heirs of world culture" (Asrul Sani, 1949).

The fire and the spirit of excitement to advance in Indonesia also felt in Singapore. A group of young people was born in August 6th, 1950 to form ASAS'50 or the 1950s Literary Force. ASAS'50, emerged by continuing a critical social spirit which have been pioneered by previous writers. It rises again in a new breath and they are determined to eliminating internal characteristics that impede the progress, justice and prosperity of society. ASAS '50 objective is to free Malay thoughts from old beliefs, shackles that inhibit freedom of mind and soul from the influence of feudalism, old-fashioned and superstitious tenets. ASAS'50 has embodied in the history of the development of modern Malay literature a pure vision for the people and the superior spirit of this art revealed in the pearl of their word of struggle: "Literature for the Community."

\section{HAMKA'S LITERARY TOUCH: BETWEEN LOVE, TRUST, RELIGION \& COLONIALIZATION}

HAMKA is a teacher, thinker, leader, scientist and excellent litterateur whose influence is so immense until now. His writings, works of art, lectures continue to survive. It is reprint and becoming several films and continues to spread on social media and still captivate the public now. His popularity is not only in Indonesia and even in Southeast Asian countries and other Islamic universe. The importance of HAMKA's literary works in Malaysia and Singapore was obvious from 1962 to 1967; where his novels were chosen as literary texts at the middle and 1st ranks for the School Certificate and Federations of Malay Certificate of Education. Furthermore, exposure to HAMKA is done through course of Malay Literature Development History which offered to students who take Advanced Malay at elementary school rank and pre-university for GCE 'A' certificate.

In this generation of students who are exposed to HAMKA novels through this school education system, emotional touch and mind are still very strong because the tragic loveres love story is quite interesting. We are reminded that love for God and family / custom overcome everything. Humans, in this matter, must guard their heart, especially for teenage readers who have just begun to know love. This is because after the love stories of Hang Tuah and Tun Teja 
in the classic texts, there is no love story worthy of being enjoyed and emulated. HAMKA through the story has filled the void of the young soul of the nation in fact, has laid the foundation of pure love that is incomparable.

\section{THE ULTIMATE POINT OF HUMAN SOUL GIVES MEANING TO A PURE LOVE}

HAMKA wrote the novel Tenggelamnya Kapal Van Der Wicjk (TKVDW) when he was 31 years old (1938); which according to him, "young blood is still flowing fast inside, and imagination and sentiment still cover the soul" (Introduction, 4th edition, $1^{\text {st }}$ edition is 1939). He explained two factors that influence the writing of this novel:

"Jelas kelihatan dua hati yang mempengaruhi jiwa. Pertama, sentiment yang bergelora. Kedua, tekanan suasana, sebab kemerdekaan masih dalam cita-cita dan penjajahan masih menekan dalam segala lapangan hidup... Sebab dia adalah puncak kekayaan jiwa yang dapat diciptakan di zaman muda dan di zaman sebelum suasana merdeka" (HAMKA, Pendahuluan, cetakan 4)

Thus, TKVDW novel was born because of the young soul of HAMKA which opposed the customary pressure and colonialism.

I was tempted to read the two novels and found that HAMKA has not only written stories that captivate the reader because of her tragic story of love, but what is more impressive is his great philosophy of love in terms of religion and humanity. This is reflected in the passage from the novel:

"Cinta yang suci adalah laksana setetes embun yang turun dari langit ke atas bumi Allah ini. Jika sekiranya bumi yang menerimanya itu subur, maka tumbuhlah di atasnya beraneka warna bunga-bunga yang harum semerbak. Menanamkan damai, aman, sentosa, insaf, rasa percaya kepada diri sendiri. Dalam hal yang begini, embun "cinta" yang setetes itu membawa manusia yang dititiknya ke mayapada yang mulia. Tetapi jika dia jatuh ke bumi yang tak subur, yang tandus dan penuh batu-batu, tidak ada yang akan tumbuh di sana, lain dari sirih memanjat batu, kuning daunnya lemah gagangnya. Orang itu menjadi putus asa, pencemburu kepada sesama manusia, hilang kepercayaan kepada nikmat yang tersimpan di dalam hidup. Atau menjadi seorang pembenci, kurang percaya, kadang-kadang pendendam dan sakit hati..." (HAMKA, TKVDW, 1999, p. 148)

HAMKA gives a high value to Love -because love can enlive the soul and the new spirit, like the dew that grows redolent flowers.

HAMKA has defined love toward human beings with love for God which creates glory, sincerity and obedience to God: "Jangan takut menghadapi cinta. Ketahuilah bahwa Allah yang menjadikan matahari dan memberinya cahaya. Allah yang menjadikan bunga dan memberinya wangi. Allah yang menjadikan tubuh dan memberinya nyawa. Allah yang menjadikan mata dan memberikannya penglihatan. Maka Allah pulalah yang menjadikan hati dan memberinya cinta. Jika hati kau diberi-Nya nikmat pula dengan cinta sebagaimana hatiku, marilah kita pelihara nikmat itu sebaik-baiknya, "kita jaga dan kita pupuk, kita pelihara supaya jangan dicabut Tuhan kembali. Cinta adalah iradat Tuhan, dikirimkan ke dunia supaya tumbuh. Kalau dia terletak di atas tanah yang lekang dan tandus, tumbuhnya akan menyiksa orang lain. Kalau dia datang kepada hati yang keruh dan kepada budi yang rendah, dia akan membawa kerusakan. Tetapi jika dia hinggap kepada hati yan suci, dia akan mewariskan kemuliaan, keikhlasan dan taat kepada Ilahi” (HAMKA, TKVDW, 1999, p. 47)

HAMKA explains that love gives soul power not a weakness:

"Lihat anak-anak muda zaman sekarang, yang menangis tersedu-sedu meminta belas kasihan perempuan, mau dia berkorban, sengsara, hina, hanyalah mencari apa yang disebut orang cinta. Salah persangkaan yang demikian, hai Guru muda. Cinta bukan mengajar kita lemah tetapi membangkitkan kekuatan, Cinta bukan melemahkan semangat, tetapi membangkitkan semangat” (HAMKA, TKVDW, 1999, p. 142).

\section{Love, Letters and Nature}

HAMKA rejects people's negative prejudice about sending letters between young people as a disgraceful act. This is written in a subtle, simple but sharp and memorable manner:

"Tetapi sama pula Zainuddin dengan Hayati semalam itu. Dia ingat surat yang dikirimkannya. Ai..barangkali dia salah, barang kali ada perkataan-perkataan janggal dan kasar terselip dalam surat itu, barangkali...barangkali berkirim surat itu adalah satu cela paling besar, sebab baik di Minangkabau atau di Mengkasar sekali pun, amat dicela orang, anak muda yang berkirim surat kepada perempuan. Barangkali, akan terlepas Hayati selama-lamanya dari tangannya, sebab dia dipandang rendah budi.

The fear and anxiety were expelled immediately. He goes away with the words: I write it sincerely; I write it with a serene soul and didn't mean to be evil, I guilty with my own heart, if the feeling is not delivered. It will be too 
dangerous if such feelings are only silent. If I am dead now ... in fact, Hayati did not know that I loved her, this can only be obtained from the notes I left behind; how poor is she, she has caused a poor creature to die desperately. No, letter is never wrong, I should have told her that I expected her, although I would be mocked and ridiculed by her. Impossible, Hayati will not do it, because her heart is so pure.

Tersingkir perasaan demikian, timbul pula kembali dalam sanubarinya rasa cinta yang mulai bersemi itu. Dilihatnya alam sekelilingnya, di sana terlukis dengan nyatanya gambaran cinta. Dilihatnya langit yang hijau dengan bintang-bintangnya, berkelap-kelip melambaikan cinta, kicut pohon bamboo dihebus udara malam, di sana didengarnya suara cinta. Didengarnya, alam itu melagukan lagu percintaan, karena memang Tuhan jadikan segenap alam ini dengan cinta" (1999, p. 38).

HAMKA has tied the feelings of love with nature directly and impressively and related the love of God that makes nature with love.

\section{Criticism for Customary Assessment}

HAMKA provides a specific chapter on considerations made by Hayati's family based on Minangkabau customs to choose a spouse. In chapter 13, entitled "Consideration", the discussion of Datuk Garang and Hayatics ninik mamak (motheres elder relatives) was carried out according to the customs used. They considered two proposals from Zainuddin and Aziz, son of Sutan Mantari. According to the usual Minang custom:

Hereng dengan gendeng

Rebut nan mendingin

Renggas nan melanting

Dikaji adat dan lembaga

Yang tidak lapuk dihujan

Nan tidak lekang dipanas

Jalan raya titian batu

Nan sebaris tidak hilang

Nan sehuruf tidak lupa

They consider some aspects like origin, ancestors, tribe, and wealth. Finaly, they received Azizes proposal because he had fulfilled the requirements according to the saying:

"Ruas telah bertemu dengan buku

Bagai janggut pulang ke dagu

Sama sebangsa keduanya

Satu bulan satu matahari"

Zainudin was rejected because:

"meskipun ayahnya orang Batipuh, ibunya bukan orang Minangkabau, mamaknya tidak tidak tentu entah di mana, sukunya tidak ada. Tidak ada perpatihnya, tidak ada ketemanggungannya. Kalau dia kita terima menjadi suami anak kemenakan kita, ke mana kemenakan kita hendak menjelang iparnya, ke mana cucu kita berbako, rumit sekali soal ini” (p. 103-104).

Hayati tidak dibenarkan memilih Zainudin, kerana ini memalukan, kerana tidak bisa seorang Mengkasar, seorang Bugis diterima menjadi menantu (p. 103).

Even if Hayati disappointed with that choice and wanted to commit suicide, it is better than shaming disrespect Ninik Mamak's decision, the custom and tradition.

"Lebih baik dia mati, senang kita; daripada dia memberi malu ninik mamak, merusak adat dan lembaga, mengubah cupak nan usali. Apa guna dia hidup kalau akan mencorengkan arang di kening dan menggores malu di muka kita? "Demikian kata Mamak Datuk Garang (p. 103)

However, finally, Aziz was accepted by the best consideration according to custom criteria, fails to be the desired husband. On the contrary, Aziz behaves vile, gambling and eventually getting caught up in debt and had to borrow money from Zainudin. Not only that, Aziz also stayed at Zainudines house and lastly forced to divorce his wife. Hayati was handed over to Zainuddin and Aziz ran away in despair and committed suicide. The unfortunate fate of Aziz who was forced to kneel on Zainuddin, is HAMKA's sharpest method on his criticism towards the Minangkabau custom. According to HAMKA, the custom has the basis of judgment that is not in accordance with real life and does not guarantee happiness to young couples. 
This smooth but sharp criticism unlike criticisms of "Kewajipan dalam Keluarga" (Duty in the Family) in the Minang custom system in his book titled Lembaga Hidup (The Living Institution) (1941):

"Dalam susunan adat Minangkabau lama kebanyakan orang merasa sukar merasakan lezat cinta berumahtangga. Karena rumahtangga bukan dikepalai oleh suami, tetapi tidak berkepala. Ada juga kepalanya, yaitu mamak-mamak yang dinamai "tungganai" tetapi dia tidak melihat setiap waktu apa yang terjadi dalam rumahtangga itu. Sebab dia di rumah isterinya pula. Jadi yang mengutakatikkan rumah itu ialah orang-orang perempuan belaka. Perempuan-perempuan yang berfikiran sempit, karena kurang pendidikan... zaman zekarang, sesudah putaran revolusi yang cepat in, dapat kita lihat bagaimananya jiwa kaum ibu di tanah adat itu. Korban pergolakan susunan lama dengan susunan baru.... Rumahtangga sebagaimana yang kita terangkan tadi adalah kehendak zaman kemajuan, dan itu juga kehendak agama Islam. Dan rumah tangga cara Minangkabau itu adalah rumah tangga adat jahiliyah” (p. 260-261).

\section{SOME CHALLENGES FROM THE COMMUNITY}

Thus are some of the criticisms of HAMKA against their own custom. This is why the HAMKA has been subjected to harsh pressure from some group of Minangkabau people. At the same time, HAMKA is also challenged by religious groups and followers who satirized him with the title "Ulama Roman" (melancholic scholars) for writing romance. This is directly explained by HAMKA himself in his book:

"Sesungguhnya bagi seorang golongan agama, mengarang sebuah buku roman, adalah menyalahi kebiasaan yg umum dan lazim pd waktu itu. Dari kalangan agama, pada mulanya, saya mendapat tantangan keras. Tetapi setelah 10 tahun berlalu, dengan sendirinya heninglah serangan dan tantangan itu, dan kian lama kian mengertilah orang apa perlunya kesenian dan keindahan dalam hidup manusia" (HAMKA, Pendahuluan, 1999, p. v)

\section{THE SINKING OF COLONIZER'S SHIP VS UNDER PROTECTION OF $K A^{\prime} B A H$}

An eye-catching HAMKA's idea is the selection of Van Der Wijck's as the name of a ship. It was a smoke ship with the most advanced technology of the day (1936), which drowned not far from Surabaya on a trip to Semarang, leading to the death of 250 passengers, including Hayati. The selection of names and historical events as the title of the novel is actually symbolic and quite meaningful. What more is the Dutch colonial factor which is one of the stresses of the atmosphere that affects HAMKA's soul to write this novel.

Van Der Wijck or his full name Carel Herman Aart van der Wijck (29 March 1840 - 8 July 1914) was the Governor-General of the Dutch East Indies who served from 17 October 1893 - 3 October 1899. He is the highest symbol of Dutch power in Indonesia whose name is attached to the name of the most sophisticated Dutch ship technology. Interestingly, historical names and events related to the Dutch colonials were unexpectedly destroyed selected by HAMKA, as his novel title, so it remains to be the mind of his novice readers until today. This technique emphasizes a message on the Dutch colonial power and supremacy, which controls transport and peoplees lives, is finally sinking unexpectedly to bring tragic death to all its passengers. It take lives and separate love-drunk couples.

The image of the sinking ship is very different and contrasting with symbol of Ka'ba, in the other HAMKA novel, Di Bawah Lindungan Ka'bah (Under protection of Kaaba) (1938), which also tells the romance of Hamid and Zainabes spouse, his adopted sister, which is hampered by differences in status and wealth.

Hamid, an orphan since the age of four, was nurtured and funded his studies by Zainab's father, Engku Haji Jaafar. Hamid loves Zainab, but they are forced to part. Hamid was forced to leave the Minangkabau land after the death of his foster father. Zainab's relatives could not accept Hamid as the pair which equivalents to Zainab. Hamid reluctantly, following his mother's advice as follows:

"Memang anak...cinta itu, adile sifatnya, Allah telah mentakdirkan dia dalam keadilan, tidak membedabedakan di antara raja-raja dengan orang minta-minta, tiada menyisihkan orang kaya dengan orang miskin, orang hina dengan orang mulia, bahkan kadang-kadang tiada juga berbeda baginya antara bangsa dengan bangsa. Tetapi aturan pergaulan hidup, tidak membiarkan yang demikian itu berlaku. Orang sebagai kita ini telah dicap dengan ,derajat bawah "e atau ,orang kebanyakan "e, sedang mereka diberi nama ,cabang atas "e , cabang atas adakalanya karena pangkat dan adakalanya karena harta benda.” (Di Bawah Lindungan Ka'bah, 1999, p. 30)

Hamid escaped and leaving Padang to Medan, then sailed to Singapore, Bangkok, Hindustan, Karaci, Basrah, Iraq, through Shara Nejd and finally reached Mecca. This happened in 1927 AD.

" ...di bawah lindungan Ka bah yang suci, terpisah dari manusia yang lain. Di sinilah saya selalu terpekur dan bermohon kepada Tuhan sarwa sekalian alam, supaya ia memberi saya kesabaran dan keteguhan hati menghadapi kehidupan. Setiap malam saya duduk beriktikaf di dalam Masjid Haram, doa saya telah berangkat ke langit hijau membubung kea lam ghaib bersama-sama permohonan segala makhluk yang makbul.” (1999, p. 46) 
Sesudah berpisah lebih kurang 2 tahun, Zainab jatuh sakit dan akhirnya meninggal dunia. Hamid akhirnya dapat berita mengenai Zainab melalui sahabatnya, Salleh. Rosna, Isteri Salleh telah mengirimkan surat Zainab kepada Hamid dan juga mengkhabarkan kematian Zainab. Hamid yang sedang mengerjakan Haji di Mekah, juga jatuh sakit dan akhirnya juga kembali ke pangkuan Ilahi di Mekah dan dikebumikan di Perkuburan Maeala. Rosna mengirim surat menjelaskan bahawa lima hari sebelum kematian Zainab, Zainab telah bangun dari tempat tidur dengan wajah yang jernih dari biasa. Dengan tersenyum Zainab berkata bahawa dia bermimpi melihat $\mathrm{Ka}^{\mathrm{ee}}$ abah dan melihat Hamid sedang tawaf. Hamid melambaikan tangan memanggilnya, supaya mendekatinya, apabila Zainab mendekati dia terbangun dari tidur (1999, p.71)

Hamid's patience and calmness in facing love obstacle by turning to God for protection, is the main message that HAMKA wants to convey through this novel. The story of Hamid who got protection from Kaaba is a clear lesson. Love for God solves everything. This is evident through the words of Salleh, Hamid's friend, when visiting Hamid's tomb before leaving Mecca:

"Hidupmu yang tiada mengenal putus asa, kesabaran dan ketenangan hatimu menanggung senggara, dapatlah menjadi tamsil dan ibarat kepada kami. Engkau telah mengambil jalan yang lurus dan jujur di dalam memupuk dan mempertahankan cinta. Allah adalah Maha Adil. Jika sempit dunia ini bagimu berdua, maka alam akhirat adalah lebih luas dan lapang, di sanalah kelak makhluk menerima balasan dari kejujuran dan kesabarannya; di sanalah penghidupan yang sebenarnya, bukan mimpi dan bukan tonil." (1999, p. 73-74)

Here, we can find HAMKA“s literary insight, preceded the thoughts of the people and their times, channeled through these two novels.

The selection of two strong literary symbols - a colonial ship drowned in tragic history and The Holy House of God which continues to be magnificent until now, comes from a combination of intelligence and sensitivity. The symbol of Colonizeres strength and greatness which destroyed is compared to the Kaaba which is the point of meeting and the protection of pure love during human and eternal love of man with their Lord.

\section{MESSAGE FOR YOUNG GENERATION}

Another literary insight from HAMKA applied as Zainuddines will, the main character in Tenggelamnya Kapal Van Der Wicjk novel. Give a try to the part "Wasiatku" (My Will) written by Zainuddin found by Muluk, his best friend:

"Saya tidak ada lagi mempunyai keluarga yang akan menerima hartaku. Ada uangku tersimpan sedikit dalam bank. Semuanya kuhadiahkan kepada sahabatku Muluk, yang telah bertahun-tahun sesakit dan sesenang dengan daku. Harta benda peninggalan ayah bundaku di Mengkasar menjadi hadiah pula untuk orang tua yang menjaganya, Daing Masiga. Karangan-karanganku kuserahkan kepada „Klub Anak Sumatrae. Sedapat-dapatnya karangan-karangan itu dicetak, dan hasil keuntungannya diambil pembantu anak-anak muda yang terlantar dalam menuju cita-citanya" (1999, p. 211).

Zainuddin gives his wealth to those who are meritorious to him. Meanwhile, the results of the intellectual property are authorized to the group of young writers that need to continue their literary dreams. This is the message of HAMKA to hand over pearls of work, literary insights and entrusting duties and responsibilities as Islamic intellectuals to the writers of Sumatra as well as the archipelago generally to continue his pioneer steps. HAMKA has a great hope for the nation and its homeland.

\section{HOPE FOR GLORY, UNITY AND NATIONAL HAPPINESS}

Muluk also found Zainuddun's last writings on the table:

"...dan akan tercapai juga kemuliaan bangsaku, persatuan tanahairku. Hilang perasaan perbedaan dan kebencian dan tercapainya keadilan dan bahagia" (1999, p. 212).

That is the hope of Zainuddin or actually the novel creator"s voice (HAMKA), through this masterpiece. Buya HAMKA hopes that his people, the Malay community, the Indonesian people, will unite and achieve glory, justice and happiness. This passage describe HAMKA ${ }^{\text {es }}$ great and pure of hope in achieving identity and a superior image of his nation and country.

\section{RECOMMENDATIONS FOR YOUNG SCHOLAR IN BUILDING WORLD CULTURE Learn the History, Reflect the Philosophy and Love the Art}

As early as 1960, 58 years ago, HAMKA has offer a suggestion for the young Muslim scholars, including the cultural and literary groups, to study about the history of Muslims and the universal Islamic culture: 


\begin{abstract}
"Hendaklah angkatan muda Islam mempelajari sejarah umatnya di Indonesia dan di luarnya sehingga ia insaf bahawa kebudayaan Islam itu universal sifatnya. Kebudayaan yang universal itulah tujuan terakhir dunia pada zaman ini. Nasionalisme sempit tidaklah panjang usianya.

Hendaklah angkatan muda Islam menuntut ilmu pengetahuan, merenungi filsafat, dan mencintai seni sebab semuanya itu adalah anjuran tegas dari agamanya sehingga kelak dapat menyumbangkan kepada dunia umumnya dan Indonesia khususnya untuk membina kebudayaan kepunyaan umat manusia sebagai hasil kecerdasan akal dan keluhuran iman. Itulah sekarang yang amat diperlukan oleh perikemanusiaan"
\end{abstract} (HAMKA, 2016, p. 249).

\title{
IV. CONCLUSION
}

The Malay-Indonesian culture has long been get the attention of intellectuals and community leaders. Interest and focus on this culture evolved over the last century (1918), and grew rapidly after the Independence of Indonesia. There was a strong awareness and hope for literary groups to act as responsible cultural fighters, literary and cultural builders of this Archipelago, not just as local or regional cultures. After the Independence, this concept of culture expanded as a national culture. This national culture wants to be fostered, reconstructed and transformed into a progressive, dynamic world culture and can be glorified as a human culture as well as the result of intelligence of reason and nobility of faith.

Traditional Literature of Archipelago has functioned as an "institution" or a casting or reference that fills philosophy, a pearl of insight into Malay culture that was passed on from generation to generation. Without this classic traditional literary source it is rather impossible to introduce Malay-Indonesian philosophy, thought, values and cultural arts. Traditional literature is a place for local wisdom that we need to develop and maintain.

The role and function of culture in traditional literature has been inherited and passed on by new literary writers. New or modern literature has played a role as the spirit originator of the Age: it also brings cultural insights and agents of cultural transformation throughout the ages. From insightful modern works, we witness the spirit of nationalism, the soul of culture, the soul of religion, the soul of the children of the archipelago who no longer want to be narrowed down by the difference of physical, regional, ethnic, national, state, skin color, social class and power.

HAMKA is a literary, cultural and religious icon that we need to learn, understand, contemplate and follow. HAMKA's works, which contain the value of knowledge, literature, whether in the form of literature, custom or religion, has given new insights into culture especially the themes of love, customs, culture and religion. HAMKA $\mathrm{s}$ works are strong with the value of Islam, and also enrich with the love of nation and motherland 's heritage. His message is of universal humanity, continues to gain attention and impact on the entire society of the Archipelago, which is a long time immersed in a cultural crisis, new colonization and identity disorder.

We need to introduce and educate our children to history and culture. They are required to read and recognize the works of HAMKA and other great scholars and litterateurs which has this glorious cultural insight. HAMKA advises young people to learn history, pondering on philosophy and loving art to build world culture. Light of Science, light of literature, light of culture, the light of religion should continue to be burned so that life can be liberated from various forms of new colonialism. In order for us to unite together to build a new fertile culture, to enjoy justice, prosperity, happiness and glory as expressed in the following HAMKA"s poems:

Bangun kekasihku umat Melayu

Belahan asal satu turunan

Bercampur darah dari dahulu

Persamaan nasib jadi kenangan

Semangat yang lemah buanglah jauh

Jiwa yang kecil segera besarkan

Yakin percaya iman pun teguh

Zaman hadapan penuh harapan

(Buya HAMKA)

\section{References}

Al-Juned, K. (2018). Hamka and Islam: Cosmopolitan Reform in the Malay World. Publisher: Southeast Asia Program Publications, an imprint of Cornell University Press. https://www.drkhairudinaljunied.com/books/hamka-andislam/

Alisjahbana, S. T. (2008). “Tugas Seni di Zaman Kita”, 1985, dalam Seni dan Sastera, Di Tengah-tengah Pergolakan Masyarakat dan Kebudayaan. Jakarta: Dian Rakyat. Cetakan 2, 2008. Cetakan 1 (1985).

Aziz, A.R.A. (2009). Nilai Mencapai Kehidupan Sejahtera: Pandangan Hamka. MALIM. 10 (2009). http://www.ukm.my/jmalim/images/vol_10_2009/a8\%20abd\%20rahman\%20aziz.pdf 
Chairunnisa, N. (2018). “ Buya Hamka dan Penolakan Novel Tenggelamnya Kapal Van der Wijck”, empo.co, Sabtu, 17 Februari 2018 11:08 WIB, https://nasional.tempo.co/read/1061606/buya-hamka-dan-penolakan-noveltenggelamnya-kapal-van-der-wijck

Buya Hamka dan Tafsir Al Azhar. Ulama Besar, Sastrawan dan Negarawan. https://buyahamka.org/bagian-sebelumtafsir/mengenang-sastrawan-besar-hamka/

Esa, S. (2000). "Islamic Roots of the Malay Philosophy of Beauty" dalam Catalogue of Exhibition.

Hadijah bte Rahmat. (2016). "Falsafah Budi, Adab dan Kesantunan Melayu - Sastera Sebagai Wadah Pendidikan". Kertas Seminar Antarabangsa Kesusasteraan Asia Tenggara (SAKAT), anjuran Majlis Sastera Asia Tenggara (MASTERA), di Kuala Lumpur, September 2016.

Hadijah bte Rahmat. (2015). Bagai Air Murni Mengalir atau Buih Hanyut- Cabaran, Keindahan dan Keunggulan Kesusasteraan Asia Tenggara. Kertas Ucap Utama Seminar Antarabangsa Kesusasteraan Asia Tenggara (SAKAT), anjuran Majlis Sastera Asia Tenggara (MASTERA), di Singapura, Julai 2015.

Hadijah bte Rahmat. (2005). "Nyala Sastera Nusantara di Tengah Peradapan Dunia" , Ucapan Perasmian Perkhemahan Sastera MLEP, anjuran Unit Bahasa Melayu, CPDD, MOE dan TPJC, 7 Jun 2005, di Institut Kepemimpinan Masyarakat Nasional ( NACLI), Singapura.

Hadijah bte Rahmat. (2007). „Membina Minda dan Budaya Melayu Baru Melalui Perekayasaan Pendidikan Bangsa dlm Jurnal e-Utama 1, Jul-Dis 2007.

Hadijah bte Rahmat. (2004). "Lukisan Sastera Melayu -Antara Keunggulan dan Kenyataan”, ceramah Sastera ASAS 50, di Perpustakaan Bedok, Singapura, pada 12 Oktober 2002.

Hakim, L. (2014). Hamka mengajar bagaimana bercinta, 17 November 2014. https://www.roketkini.com/2014/11/17/hamka-mengajar-bagaimana-bercinta/

HAMKA. (1999). Di bawah lindungan Ka'bah (Cetakan 23). Jakarta: Bulan Bintang.

HAMKA. (1999). Tenggelamnya kapal Van der Wijck (Cetakan 23). Jakarta: Bulan Bintang.

HAMKA. (2016). "Kebudayaan Dipandang Dari Segi Ajaran Islam”, Prasaran Seminar Kebudayaan Nasional 26 -29 Mei 1960 di Semarang, dalam Pandangan Hidup Muslim. Jakarta: Gema Insani.

HAMKA. (2016). Lembaga Hidup. Jakarta: Republika Penerbit.

Kasim, K.B.A., \& A. Muhamad. Saranan HAMKA terhadap Perpaduan Bangsa Serumpun Malaysia Indonesia,HAMKA Recommendation for Malaysia - Indonesia Homogenous Race Unity, International Journal of the Malay World and Civilisation Kamarul Baharin A. Kasim \& Asyaa. $\underline{\text { http://journalarticle.ukm.my/8543/1/Saranan_HAMKA_terhadap_...pdf }}$

Tamara, E. (2017), "Bab 1- Latar Belakang Kebudayaan”, http://eprints.uny.ac.id/53142/5/BAB\%20I\%2013406241003.pdf

Talib, A. L. (2014). HAMKA - Ulama, pemimpin, sasterawan. Selangor: PTS Publishing House.

http://jkomunitas.blogspot.com/2009/11/perjalanan-kongres-kebudayaan-di.htmlt

http://borobudurlinks.blogspot.com/2009/11/magelang-dan-sejarah-kongres-kebudayaan 24.htmlihat 